http://dx.doi.org/10.12775/szhf.2016.012

DMitry A. LeONTIEV

Lomonosov Moscow State University, Moscow, Russia

DLEON@MAIL.RU

\title{
Rozwój osobowości w naturalnych i utrudnionych warunkach*
}

Tradycyjne mechanizmy rozwoju osobowości rozpatrywane są w psychologii jako mechanizmy wzrostu i dojrzewania wskutek naturalnej dynamiki psychologicznych struktur oraz współdziałania indywiduum $\mathrm{z}$ otaczającą rzeczywistością społeczną. Mówi się o tym we wszystkich czołowych teoriach i periodyzacjach rozwoju. Mniej zbadane i usystematyzowane są mechanizmy rozwoju w niesprzyjających dla człowieka warunkach, kiedy nie wszystkie kluczowe czynniki rozwoju działają w podobnym kierunku. Mimo że badania studium utrudnionego rozwoju sięgają dawnych tradycji psychologii indywidualnej Alfreda Adlera i jego pracy poświęconej fizycznej niepełnosprawności (niepełnowartościowości) ${ }^{1}$, liczne prace na ten temat są jednak zdekompletowane i brakuje uogólnionych teoretycznych modeli.

Szczególną kwestią jest to, że problem specyfiki osobowości, jej funkcjonowania i rozwoju u osób niepełnosprawnych ${ }^{2}$ znajdował do tej pory niewielkie odzwierciedlenie w literaturze, zarówno rosyjskiej, jak i zagranicznej.

* Zob. Д. А. Леонтьев, Развитие личности в норме и в затрудненных условиях, „Cultural-Historical Psychology", 2014, vol. 10, no. 3, p. 97-106.

${ }^{1}$ A. Adler, Studie über Minderwertigkeit von Organen, Berlin 1907, s. 127. Zob. A. Adler, Sens $\dot{z} y c i a$, tłum. Maria Kreczowska, Warszawa 1986, s. 99-115.

${ }^{2}$ OB3 (ограниченные возможности здоровья) - ograniczone możliwości zdrowia. W tym miejscu należy podkreślić, że jest to termin naukowy wypracowany przez Leontieva. 
Większa część dostępnych badań uwzględnia tylko ilościową specyfikę ludzi niepełnosprawnych, jako określonej nozologicznej (chorobowej) grupy. Specyfika ta jest wyrażana poprzez istotne różnice $\mathrm{w}$ nasileniu cech psychologicznych jednostki. Jednakże nawet w odniesieniu do różnych chorób psychicznych wykazano, że cechy ich osobowości niosą niespecyficzny w stosunku do nozologii charakter, osobowość chorego jest niekoniecznie chorą osobowością, i właśnie stopień bezpieczeństwa podstaw osobowości jest głównym czynnikiem sukcesu wyzdrowienia albo znacznej poprawy stanu przy najróżniejszych chorobach ${ }^{3}$. U osób z niepełnosprawnością nie są zaburzone centralne funkcje zapewniające sprawne funkcjonowanie psychiki, lecz funkcje obwodowe - sensoryczne i motoryczne, zapewniające współdziałanie podmiotu ze światem, instrumentalną organizację jego przedmiotowo-praktycznej aktywności. Zaburzenia te mogą mieć bardzo istotny wpływ na rozwój jednostki w ogóle. A. Leontiev ${ }^{4}$ zwrócił uwagę na to, że taka czysto somatyczna wada, jak wrodzone zwichnięcie stawu biodrowego może mieć o wiele większy wpływ na los dzieci i młodzieży niż rzeczywiste zaburzenia natury psychicznej, z powodu ograniczeń rzutujących na jego aktywność 5 . Niemniej jednak dziś brakuje systematycznej analizy, która opisywałaby korelację osobowościowego rozwoju osób niepełnosprawnych z osobistym rozwojem cielesnym i psychicznym osób niedotkniętych niepełnosprawnością. $\mathrm{W}$ związku z tym celem tego artykułu jest analiza właściwości osobowych i cech osobowościowego rozwoju osób niepełnosprawnych oraz zbudowanie teoretycznego modelu, który może stanowić podstawę badań empirycznych i praktycznej pracy z osobami potrzebującymi pomocy psychologicznej.

\section{Ograniczone możliwości zdrowia jako utrudnione warunki rozwoju}

W psychologii rozwojowej tradycyjnie rozpatrywano dwie podstawowe siły albo dwa czynniki, wpływające na przebieg i wyniki rozwoju. Pierwszy czynnik: samą jednostkę [ludzką] można rozpatrywać jako to, co jest dane albo zakodowane. Mowa tutaj przede wszystkim o genotypie, jak również jeżeli analizujemy rozwój jednostki nie od chwili jej pojawienia się na świecie, a od pewnego późniejszego momentu - jej ukształtowane w danej chwili solidne wieloaspektowe podłoże, z uwzględnieniem mózgowych podstaw

\footnotetext{
3 Д. А. Леонтьев, Психология смысла [Psychologia sensu], Москва 1999, с. 487.

${ }^{4}$ Д. А. Леонтьев, Activity, consciousness, and personality, Moscow 1977, s. 304.

${ }^{5}$ Zob. A. Wojciechowski, Idee słabości, Toruń 1998 [przypis autora].
} 
psychiki. Mówimy o pewnych założonych predyspozycjach, które zostały rozwinięte. Drugi czynnik: środowisko w najszerszym tego słowa znaczeniu, w tym rzeczywistość społeczno-kulturowa. Trzeci czynnik rozwoju wyodrębnił się w chwili pojawienia i ulokowania w nauce psychologicznych koncepcji, w których osobowość nie jest pojmowana jako bierna marionetka, na którą oddziałują wszelkiego rodzaju siły, lecz jako dynamiczny podmiot mający wpływ na własne życie i działanie. Podmiot ten nie może zostać zdeprecjonowany tylko do stanów „wewnętrznych” czy „zewnętrznych”, ale powinien być rozpatrywany pod kątem osobowości, jego pozycji, postawy i działalności ${ }^{6}$. Bardziej szczegółowy związek pomiędzy tymi trzema stronami lub wymiarami rozwoju rozpatrywany jest w odrębnej publikacji ${ }^{7}$.

Działanie każdego z tych trzech czynników może być oceniane pod kątem tego, w jakim stopniu przyczynia się on do rozwoju. Poszczególne inklinacje mogą być wyrażone silniej bądź słabiej. Bardziej istotnym momentem jest występowanie pierwotnych zaburzeń morfologicznych i funkcjonalnych określanych jako ograniczone możliwości zdrowia (dalej: OMZ). W psychologii od dawna przeprowadzano uzasadnioną linię podziału między procesami rozwoju i wyzdrowienia, między zdrowiem a dojrzałością; dość oczywiste jest to, że OMZ występują jednocześnie w charakterze utrudnionych warunków rozwoju (dalej: UWR). O ograniczaniu możliwości rozwoju można byłoby mówić w sposób niewłaściwy, gdy OMZ nie ograniczałyby możliwości rozwoju, co wymaga wzmożonego wysiłku i nakładu większych zasobów niż w przypadku prawidłowego rozwoju.

Zadaniem normalnego rozwoju osobowości jest stać się niezależną jednostką $\mathrm{w}$ psychologicznym tego słowa znaczeniu, pełnoprawnym podmiotem w odniesieniu do interakcji społecznych i prawnych, tzn. poczytalnym podmiotem, posiadającym prawa i zdolnym brać na siebie zobowiązania, ponosić odpowiedzialność i zdobywać stosowne do tej odpowiedzialności prawa ${ }^{8}$. W odróżnieniu od człowieka niecałkowicie psychicznie stabilnego (labilnego), który nie może zostać pełnoprawnym podmiotem praw i obowiązków, człowiek z somatycznymi zaburzeniami jest w stanie sprostać zadaniom rozwojowym i uznawany jest przez społeczeństwo za pełnoprawnego obywatela. Stoją przed nim zadania morfologiczno-funkcjonalnego dojrze-

\footnotetext{
${ }^{6}$ K. Dąbrowski, Positive Disintegration, Little, Brown, and Co, Boston 1964, s. 132.

${ }^{7}$ A. Леонтьев, Личностное изменение человеческого развития [Osobisty wymiar ludzkiego rozwoju], „Вопросы психологии”, 2013, nr 3, с. 67-80.

${ }^{8}$ Tamże.
} 
wania, adaptacji do otaczającego świata, socjalizacji i kształtowania siebie jako autonomicznego podmiotu własnych działań, zdolnego do ponoszenia odpowiedzialności za siebie. W tym znaczeniu rozwój osobowości ludzi z niepełnosprawnością jest odmianą normalnego, a nie anomalnego rozwoju, albo dysontogenezy ${ }^{9}$ [zakłócenie indywidualnego rozwoju organizmu - przyp. tłum.]. Jednak różnica polega na tym, że w porównaniu do osób stosunkowo zdrowych, jednostki niepełnosprawne rozwiązują problemy w odmiennych i deficytowych w zasoby warunkach.

Pojęcie zasobów, zaczerpnięte $\mathrm{z}$ ekonomii i teorii zarządzania, przez ostatnie dziesięciolecia zaczyna zajmować w psychologii osobowości coraz ważniejsze miejsce. Powiązane jest to ze stopniowym przejściem od postaci biernej osobowości, kierowanej przez dyspozycje i zewnętrzną stymulację, do postaci jednostki aktywnej, dynamicznej stawiającej cele i dążącej do ich osiągnięcia. Zasoby odnoszą się do celów, ich występowanie ułatwia rozwiązywanie problemów, a brak bądź niedostatek to zadanie utrudnia. Zasoby występują tylko tam, gdzie jest zadanie, cel. Jeśli ktoś nie ma żadnych zadań i celów, wówczas nie można mówić o istnieniu zasobów.

Niedostatek zasobów powoduje trudności. Pojęcie „trudności” odgrywa kluczową rolę w tym modelu. Oznacza to, że rozwiązanie zadania łączy się z większym nakładem różnych zasobów i mniejszą pewnością powodzenia niż rozwiązanie prostego zadania. W powszechnej świadomości, która charakteryzuje się infantylnym obrazem świata, stosunek do pojęcia „trudność" jest szczególnie negatywny. Kultura masowa ma tendencję do wypierania, usuwania wszelkich wzmianek na temat trudności w rozwiązywaniu jakichkolwiek zadań. Jednak, jak wykazał F. Wasiluk ${ }^{10} \mathrm{~W}$ swojej wersji egzystencjalnego świata, trudność jest obiektywną ontologiczną cechą świata zewnętrznego, w którym egzystujemy. Świat zewnętrzny, zgodnie z tym wzorcem może być trudny albo łatwy. Przystępny świat zewnętrzny to ten, w którym wszystkie nasze życzenia spełniane są bez przeszkód, w którym łatwo dostępne są ich obiekty. Niemowlę, egzystujące w warunkach normalnych, żyje w łatwym świecie zewnętrznym. Ale w miarę jak rośnie, rozwija się i dorośleje, świat zewnętrzny staje coraz bardziej trudny. Pojawia się dystans między tym, co pożądane i realizacją pragnień. Świat dorosłego z definicji jest trudny: żeby

${ }^{9}$ M. M. Semago, Developmental psychology in the postnonclassical scientific world view, Publ. APK and PPRO, Moscow 2010, c. 332.

${ }^{10}$ Ф. Е. Василюк, Психология переживания: анализ преодоления критических ситуаций [Psychologia doświadczenia: Analiza przezwyciężenia sytuacji kryzysowych], Москва 1984, с. 200. 
urzeczywistnić swoje pragnienia, człowiek dorosły powinien rozwiązać wiele problemów i zaangażować $\mathrm{w}$ to sporo wysiłku. Funkcja rodzica polega na tym, żeby z jednej strony pomóc dziecku być dzieckiem, niwelując pojawiające się trudności, ale $\mathrm{z}$ drugiej strony, żeby ułatwić mu szansę stania się dorosłym. Nie powiodło się temu, kto w dzieciństwie nie miał wystarczających zasobów rodzicielskiego wsparcia, wcześnie został pozbawiony możliwości dzieciństwa. Najczęściej jest to problem sierot i innych osób, które nie dorastają w rodzinie, lecz w odpowiednich społecznych instytucjach. Dla dorosłego jednak trudności świata zewnętrznego, rozdźwięk między życzeniem a jego realizacją jest czymś naturalnym. Forma społecznej patologii, lustrzane odbicie problemów dysfunkcyjnych dzieci, problem rozpieszczonych dorosłych, ich infantylizm są diagnozą naszych czasów.

Wzajemny stosunek możliwości człowieka i tych zadań, które on rozwiązuje, stanowi niezwykle istotny czynnik psychologicznego rozwoju. Mihály Csíkszentmihályi ${ }^{11}$ zwrócił uwagę na wzajemny stosunek zdolności i zadań jako na czynnik wpływający na rozwój. Jeśli zdolności człowieka w znacznym stopniu przekraczają zadania, które ma do wykonania, to doświadcza on stanu nudy, pasywności i apatii. Jeżeli zadania te silnie przekraczają w swojej złożoności te możliwości, dominuje stan niepokoju, lęku, który jest niekomfortowy. Ale jeżeli zadania, które stoją przed człowiekiem, albo które on sam sobie stawia, leżą na granicy jego możliwości, powodują w człowieku napięcie, ale jednocześnie nie wywołują uczucia niemożności i beznadziejności, wówczas pomagają one człowiekowi wznieść się ponad siebie i dalej rozwijać swoje umiejętności, swoje możliwości i swoje siły. Mamy do czynienia z rozwojem, związanym ze zwiększeniem i pogłębieniem wewnętrznej złożoności, co pozwala dostosować się do różnorodności otaczającego świata, zwiększa poziom interakcji ze światem zewnętrznym. Powstaje optymalny psychologiczny stan „poza granicami nudy i lęku” (taki tytuł nosiła pierwsza książka Csíkszentmihályi z roku 2011) stan przepływu. W ten sposób natura wynagradza za rozwój, za włożone wysiłki, za wzrost wewnętrznej złożoności i wewnętrznych możliwości.

${ }^{11}$ M. Csíkszentmihályi, Поток: психология оптимального переживания [Przepływ: Psychologia optymalnego doświadczenia], Москва 2011, с. 460. Wyd. pol. M. Csíkszentmihályi, Przepływ. Psychologia optymalnego doświadczenia, przeł. Magdalena Wajda-Kacmajor, Taszów 2005. 


\section{Zasoby rozwoju}

W odniesieniu do człowieka, który realizuje swoje cele, przyjęto ogólnie rozróżniać zasoby:

1. fizjologiczne albo fizyczne,

2. społeczne,

3. psychologiczne.

Do pierwszych zalicza się możliwości organizmu, do drugich - pomoc i wsparcie, które można uzyskać od innych ludzi, grup i instytucji społecznych, do trzecich - zasoby związane ze stopniem rozwoju psychologicznych mechanizmów regulacji i samoregulacji. Oprócz tego zasoby powiązane z określonymi elementami osobowości, motywacji, dla przykładu, tradycyjnie w charakterze jednego z głównych psychologicznych środków rozpatrywana była „siła woli i charakteru”. Psychologiczne zasoby można z kolei klasyfikować w sposób bardziej szczegółowy, jednak w tym kontekście nie będziemy się zagłębiać w dalszą klasyfikację.

Fizjologiczne, fizyczne zasoby i możliwości naszego organizmu to najbardziej podstawowe cechy, zbliżające nas do innych żyjących istot. Rozwijają się one od chwili urodzenia, osiągają swoje maksimum w okresie wczesnej dorosłości, po czym następuje ich stopniowy spadek. Stosunek do własnej fizyczności jako zasobu, narzędzia, instrumentu do rozwiązywania problemów jest właściwy dla zachodniej mentalności; dla wschodniej świadomości typowe jest inne spojrzenie, ale nie będziemy na tej różnicy skupiać uwagi.

Wszelkie inklinacje mogą być wyrażone w silniejszy lub słabszy sposób. Najważniejszym punktem jest występowanie pierwotnych zaburzeń morfologiczno-funkcjonalnych określanych przez pojęcie ograniczonych możliwości zdrowia (OMZ) Ograniczone możliwości zdrowia jako takie nieuchronnie powodują utrudnione warunki rozwoju, które charakteryzują się wyższym zapotrzebowaniem na zasoby: to, co dla człowieka bez OMZ przychodzi łatwo i "automatycznie”, od człowieka z OMZ wymaga dużego wysiłku, większego nakładu sił, każde zadanie jest dla niego trudniejsze. Utrudnione warunki rozwoju można zdefiniować jako nieoptymalny stan biologicznych bądź społecznych przesłanek osobowościowego rozwoju, wymagający znacznie intensywniejszych wysiłków dla wykonania zadań rozwojowych i odzwierciedlający wskutek tego podniesione wymagania stawiane przed jednostką. 
Należy szczególnie podkreślić, że jest to właśnie charakterystyczne dla warunków lub warunków wstępnych rozwoju, ale nie dla samego rozwoju. OMZ nie tyle stawia granice możliwościom rozwoju, ile wymaga wzmożonych wysiłków i nakładu znaczących zasobów, w odróżnieniu od sytuacji prawidłowego, niezakłóconego rozwoju. To, czy zwiększony poziom wymagań jest rzeczywiście ograniczeniem możliwości, zależy od dwóch pozostałych czynników - od tego, na ile środowisko będzie wspierać rozwój i zapewniać niezbędne środki, i od tego, na ile jednostka okaże się gotowa, zmotywowana i zdolna do zastosowania intensywnego wysiłku, aby sprostać społecznym wyzwaniom i indywidualnej sytuacji rozwojowej.

Kwestię niejednoznacznych psychologicznych skutków deficytu fizycznych zasobów po raz pierwszy podjął się Adler w swojej klasycznej rozprawie o fizycznej niepełnosprawności (niepełnowartościowości) ${ }^{12}$, odkrywając i opisując w tej publikacji zjawisko kompensacji i nadkompensacji. Przy czym kompensacja i nadkompensacja mogą być realizowane zarówno kosztem alternatywnych fizycznych środków (ponadprzeciętnie rozwinięty słuch i węch u niewidomych, siła rąk u ludzi z zaburzeniami narządów ruchu), jak i kosztem zasobów psychologicznych (wysokie ambicje, motywacja do osiągnięć i władzy u ludzi niskiego wzrostu).

W miarę rozwoju społeczeństwa tworzone były mechanizmy kompensacji fizycznej niepełnowartościowości przez środki społeczne. We wczesnych etapach rozwoju ludzkiego społeczeństwa fizyczna niepełnowartościowość nie podlegała kompensacji. W antycznej Sparcie, jak wiadomo, cherlawe dzieci zrzucano ze skały, w średniowiecznej Japonii starych ludzi odprowadzano na śmierć na świętą górę itd. Jednakże stopniowo bliscy i społeczeństwo, ogólnie rzecz biorąc, zaczęli troszczyć się o tych, którzy sami nie potrafią o siebie zadbać.

Sytuację społeczną i jej wpływ na osobowość człowieka z OMZ można rozpatrywać w co najmniej dwóch aspektach. Pierwszy aspekt wyznacza makrospołeczna sytuacja w społeczeństwie, przejawiająca się w ogólnej polityce państwa i stosunku społeczeństwa wobec osób z OMZ. Aspekt ten obejmuje mechanizmy określania niepełnosprawności, ustalania renty oraz inne mechanizmy ukierunkowanej pomocy społecznej, możliwości i mechanizmy zatrudnienia, zdobywanie średniego i wyższego wykształcenia, szczególne rozwiązania miejskiej infrastruktury (podjazdy itp.) albo ich brak. Drugi

12 A. Adler, Studie über Minderwertigkeit von Organen, Urban \& Schwarzenberg, Berlin 1907, s. 127. Zob. A. Adler, Sens życia, tłum. Maria Kreczowska, Warszawa 1986, s. 99-115. 
aspekt dotyczy mikrospołecznej sytuacji w otoczeniu konkretnego człowieka, obecności w jego otoczeniu ludzi zdolnych pełnić funkcję pomocy społecznej, zarówno w moralno-psychologicznym, jak i praktycznym wymiarze. Ograniczone możliwości zdrowia (OMZ) podnoszą stopień zależności człowieka od pomocy społecznej (przy czym ta zależność może być dla niego uciążliwa), ale nie całkiem sprzyjająca makrospołeczna sytuacja zwiększa zależność jednostki od okoliczności mikrospołecznych. Jeżeli mikrospołeczna sytuacja również pozostawia wiele do życzenia, istnieją uzasadnione powody, by mówić o utrudnionych warunkach społecznych rozwoju, nawet w warunkach sprzyjającej sytuacji makrospołecznej. Tak jak we wszystkich innych sytuacjach społecznych wpływających na osobowość, oddziaływanie małych grup kontaktowych jest zawsze silniejsze niż wpływ na osobowość ogólnych makrospołecznych warunków i zmniejsza wpływ tych ostatnich. Połączenie trudności, wynikających z biologicznych uwarunkowań rozwoju (OMZ) i trudności, wytworzonych przez społeczne (zwłaszcza mikrospołeczne) konteksty, wywiera kolosalną presję na osobowość. W tej sytuacji jedynymi jej zasobami zostają zasoby osobowościowe, na które spada cały ciężar rozwoju.

Kiedy artykuł niniejszy był przygotowywany do druku, zostały opublikowane wyniki innych obszernych badań w całości potwierdzające nasze przypuszczenia ${ }^{13}$. Autorzy tych badań, porównując cechy psychicznego dobrobytu, sytuację rodzinną i cechy osobowościowe dzieci i młodzieży, doszli do wniosku, że w trudniejszych warunkach wychowawczych w rodzinie (wyznacznikiem trudności były zgłaszane w deklaracjach respondentów dane o strukturze rodziny, statusie społeczno-ekonomicznym i rodzinnych praktykach wychowawczych) cechy osobowościowe mają o wiele większy wkład w dobrobyt psychiczny niż w rodzinach cechujących się przyjazną atmosferą i sprzyjającymi warunkami.

W sytuacji inkluzyjnego kształcenia samo w sobie integrujące środowisko występuje zarówno jako makrospołeczny jak i mikrospołeczny zasób społecznej kompensacji fizycznej niepełnosprawności. Makrospołeczny zasób społecznej kompensacji fizycznej niepełnosprawności to zapewniane przez państwo i władze lokalne prawne gwarancje (możliwość podjęcia studiów na uczelni wyższej) i materialne zasoby w celu zapewnienia pełnowartościowej socjalizacji osób z OMZ. Mikrospołeczny zasób społecznej kompensacji fizycznej niepełnosprawności opiera się na nieobojętnej postawie wobec uczą-

${ }^{13}$ H. R. Slobodskaya, O. A. Akhmetova, T. O. Rippinen, Does personality matter more in difficult circumstances?, "Journal of Research in Personality", 2014, vol. 48, s. 33-44. 
cych się osób z OMZ i wsparciu tych osób na płaszczyźnie interpersonalnej ze strony administracji instytucji zajmującej się kształceniem inkluzyjnym, pedagogów i psychologów, a także innych uczniów. Bez tworzenia sprzyjającego otoczenia mikrospołecznego istnieje ryzyko, że wszelkie makrospołeczne zasoby przerodzą się w biurokrację.

Nawet w rozwiniętym społeczeństwie, traktującym osoby z OMZ na równi z osobami o prawidłowym rozwoju i aktywnie wspierającym je na makroi mikrospołecznym poziomie, normatywne wymogi dotyczące ich społecznego rozwoju są stosunkowo niższe, co daje możliwość tym osobom - według ich własnego uznania - stawiać samym sobie poprzeczkę wymagań na różnych poziomach. Mogą one świadomie zajmować pozycję osób niepełnosprawnych, biorąc za pewnik obniżenie oczekiwań w stosunku do nich w porównaniu z pozostałymi i korzystając z przywileju oszczędzania wysiłku, bądź rezygnować z tego przywileju, ubiegając się o traktowanie ich na równi z innymi osobami, mając świadomość tego, że nakłady ich pracy o wiele przekraczają te, które wkładają pozostali, żeby osiągnąć te same cele.

Dlatego też decydującym czynnikiem określającym drogę rozwoju osób z OMZ staje się, w ostatecznym rozrachunku, właśnie „trzeci czynnik”, a mianowicie psychologiczne zasoby, których esencją jest pozycja jednostki względem własnej społecznej sytuacji. Należy zaznaczyć że ten wybór, którego świadomie albo nieświadomie dokonuje każdy człowiek z OMZ, jest osobistym wyborem każdego, kto przechodzi od rozwiązywania problemów „sytuacji społecznej rozwoju” do sformułowania i rozwiązania nieobowiązkowych, ale możliwych zadań „osobistej sytuacji rozwoju”. Nie podlega dyskusji, że dla ludzi z OMZ ta sytuacja wyboru jest o wiele bardziej dotkliwa zarówno ze względu na swoją krytyczność i nieuchronność, jak również ze względu na wagę konsekwencji dokonanego wyboru.

\section{Wyzwania niepełnosprawności i odpowiedzi osobowości}

Na przestrzeni dziejów oraz w psychologicznej praktyce znajdziemy wiele przykładów kompensacji deficytu fizycznych zasobów kosztem siły ducha, siły woli i zdolności do zbudowania własnego życia tak, aby zminimalizować skutki odchyleń rozwojowych. Znani pisarze i poeci (Homer, Milton), politycy (Roosevelt), naukowcy (Hawking, Bachtin), którzy, bez względu na stan niepełnosprawności, osiągnęli takie powodzenia w swojej dziedzinie, że w odniesieniu do nich słowo „ograniczony” byłoby bluźnierstwem. Doktor nauk technicznych A. Bielopuhov, który był w Związku Radzieckim słynnym 
alpinistą po wypadku samochodowym niemal stracił obie nogi. Po jakimś czasie, $\mathrm{w}$ zespole $\mathrm{z}$ innymi alpinistami dokonał specjalnie przygotowanej wspinaczki na Elbrus ${ }^{14}$. Moja nauczycielka, znana psycholog E. Artemjeva, dusza Wydziału Psychologii Uniwersytetu Moskiewskiego im. Łomonosowa $\mathrm{w}$ latach osiemdziesiątych $\mathrm{z}$ powodu poważnych zaburzeń hormonalnych również straciła obie nogi, w dodatku mając sporą nadwagę. W tych okolicznościach kierowała ona nie tylko pracą dużej liczby studentów i absolwentów, ale również napisała i obroniła habilitację, która stanowiła novum w psychologii i której znaczenie ćwierć wieku po obronie tej pracy i śmierci uczonej, która nastąpiła kilka miesięcy później, nadal rośnie.

Te i wiele innych przykładów pokazują, że do wyzwania, jakim jest dla jednostki niepełnosprawność, można mieć różny stosunek. Wyzwanie jest taką znacząca sytuacją egzystencjalną, która dopuszcza różne możliwości świadomego działania: jako aktywna konfrontacja z sytuacją (przyjęcie wyzwania) oraz unikanie i dystansowanie się od niej. Jeszcze w 1980 roku w badaniach Suzanne Kobasy i Salvatore Maddi zostało ustalone, że podjęcie wyzwania, czyli gotowość do działania przy jednoczesnym braku gwarancji sukcesu, jest istotną częścią zestawu cech osobowościowych o nazwie "hardiness" albo „odporność i wytrzymałość życiowa"15. Potwierdzono, że wytrzymałość jest najsilniejszym czynnikiem skutecznej odporności w stresujących okolicznościach; u ludzi z wysoką odpornością życiową nie rozwijają się znane medyczne następstwa długotrwałych stałych stanów stresogennych, które w całej rozciągłości przejawiają się u osób z niską odpornością życiową. Dlatego też odmienny stosunek do tych wyzwań może doprowadzić do zupełnie różnych, nie tylko psychologicznych, ale także medycznych konsekwencji.

A priori niesprzyjająca dla jednostki sytuacja niepełnosprawności, nawet wrodzonej, z punktu widzenia współczesnych spojrzeń na psychologię osobowości i na psychologię zdrowia, nie może być rozpatrywana jako jednoznacznie narzucająca problemy adaptacyjne. Dzisiaj z pewnością można umacniać się w przekonaniu, że do faktu medycznej diagnozy, na podstawie której społeczeństwo diagnozuje niepełnosprawność, sam człowiek, któremu w tym zakresie się nie poszczęściło, może ustosunkować się różnie. Niepełnosprawność tworzy szczególną strukturę wyzwań dla tej kategorii ludzi, w spo-

${ }^{14}$ А. К. Белопухов, Я - спинальник. (Чуть медленнее чем Andante), Москва 1993, с. 224.

${ }_{15}$ Д. А. Леонтьев, Е. I. Rasskazowa, Teст жизнестойкости [Test odporności życiowej], Moсква 2006, с. 63. 
sób istotny różniącą się od struktury wyzwań, z którymi muszą sobie radzić zdrowi rówieśnicy. Jednocześnie nie możemy zgodzić się z tezą, że krytyczna sytuacja, której nie można rozwiązać poprzez działania przedmiotowe lub transformację świadomości, może być rozwiązana tylko dzięki przeżyciom i zmianie interpretacji ${ }^{16}$. W przeciwieństwie do psychologicznych reakcji, na przykład mechanizmów obronnych lub strategii radzenia sobie, odpowiedzi na wyzwanie niepełnosprawności udziela cała istota zintegrowanej osobowości, bez opierania się na istniejących automatyzmach, tzn. w trybie bycia-w-świecie, egzystencjalnego funkcjonowania. Właśnie poprzez świadome twórcze budowanie życiowej taktyki i strategii, dzięki pracy jednostki nie tylko ze swoją wewnętrzną rzeczywistością, ale przede wszystkim z rzeczywistością relacji ze światem jest możliwa akceptacja sytuacji krytycznej. Ponadto umożliwia to restrukturyzację relacji jednostki ze światem w warunkach ich rozkładu lub początkowego braku możliwości relacji, które jawią się dla większości jako oczywiste. Możemy przeprowadzić analogię do sytuacji przywrócenia psychologicznych funkcji przy lokalnych uszkodzeniach podłoża mózgowego ${ }^{17}$ albo korekcji niewłaściwie ukształtowanych nawyków ${ }^{18}$ : w obu przypadkach pierwszym ogniwem procesu przywrócenia występuje deautomatyzacja zaburzonych procesów, czyli ich maksymalnie pełne i świadome rozwinięcie. Tylko w ten sposób można odbudować uszkodzone ogniwa organizowanych funkcji systemowych, zastępując je innymi. Jeżeli zaś człowiek w krytycznych okolicznościach nadal reaguje automatycznie, polegając na swoim bądź cudzym sprawdzonym doświadczeniu, ryzykuje tym, że nie sprosta wyzwaniom, co w konsekwencji wyraża się w psychopatologicznych albo psychosomatycznych objawach.

Należy rozróżniać stosunek do wyzwania niepełnosprawności jako do problemu i jako do zadania. Postrzeganie wyzwania jako problemu, przede wszystkim, przejawia się w uświadomieniu sobie siebie jako jednostki problemowej, jako przedstawiciela specjalnej kategorii („Tak, nie jestem taki jak wszyscy, mam ograniczone możliwości, stwarzam problemy i korzystam z zasobów wsparcia społecznego"). W skrajnej postaci przejawia się to w formie

\footnotetext{
${ }^{16}$ Ф. Е. Василюк, Психология переживания: анализ преодоления критических ситуаций, Москва 1984, с. 200.

${ }_{17}$ А. Р. Лурия, Высшие корковые функции человека и их нарушения при локальньх поражениях мозга [Wyższe funkcje korowe człowieka $i$ ich zaburzenia przy miejscowych uszkodzeniach mózgu], Москва 1969, с. 504.

18 Д. А. Леонтьев, Психологические основы развития ребенка и обучения [Psychologiczne podstawy rozwoju i uсzenia się dzieci], Смысл [Sens], Москва 2009, с. 423.
} 
rentowego, pasożytniczego sposobu myślenia, gdzie wada fizyczna odgrywa rolę środka w celu uzyskania renty i wzmacnia tendencję do udawania. Jeżeli wyzwanie rozumiane jest jako zadanie, to przeciwnie, człowiek nie zgadza się na traktowanie siebie, jako innego, nie chce być zaliczany do odrębnej kategorii. Stara się on w większym stopniu opierać się na wewnętrznych zasobach, „orientować się na działanie” w terminach teorii samoregulacji i kontroli działania J. Kulja. Istnieje dawna maksyma mówiąca o tym, czym różni się zdrowy człowiek od neurotyka: zdrowy człowiek transformuje problem $\mathrm{w}$ zadanie, a neurotyk transformuje zadanie w problem. Zgodnie z tym kryterium ludzie, którzy należą do osób z OMZ, nierzadko są o wiele zdrowsi, od tych, którzy formalnie nie są zaliczani do tej kategorii.

\section{Kompensacyjne mechanizmy rozwoju w utrudnionych warunkach}

Powyższy punkt widzenia pozwala postrzegać psychologiczną sytuację osób z OMZ jako sytuację ciągłego rozwiązywania przez człowieka z ograniczonymi zasobami egzystencjalnych zadań i potrzebę przezwyciężenia ograniczenia tych zasobów ze względu na przyjęcie wyzwania niepełnosprawności.

Wyzwanie, z którym zderzają się badacze i praktycy, pracując z takimi ludźmi, polega na tym, żeby przeanalizować i zrozumieć z perspektywy współczesnej psychologii to, w jaki sposób zbudowany jest ich różniący się od naszego system samoregulacji, jak również w jaki sposób i kosztem czego przekształcają oni swoją słabość w siłę. Ponadto badacze próbują znaleźć sposób, aby zorganizować przekazanie takiego pozytywnego doświadczenia osobom z OMZ, którym na razie nie udaje się skutecznie radzić sobie z wyzwaniami, które stawia przed nimi życie. I nie przed nimi, ale też przed tymi, których uważa się za „zdrowych”, „normalnych”, „grupę kontrolną”, na analizie których opiera się dziś głównie psychologia jako nauka. Ten „normocentryzm" nie jest bardziej uzasadniony niż nozologiocentryzm [tzn. chorobocentryzm - przyp. tłum.] sto lat temu, rozpatrujący każdą osobowość w świetle obecności u niej jakiejś choroby. Zarówno zdrowie, jak i choroba stanowią sposoby funkcjonowania jednostki, które ona tworzy na podstawie istniejących przesłanek. Przesłanki te jednak jednoznacznie nie zakładają tych sposobów i mogą one przybierać różne formy, w zależności od interpretacji przez człowieka stojących przed nim wyzwań oraz zależności od świadomie albo nieświadomie wybieranej przez niego strategii reakcji. Jak pokazują dane $\mathrm{z}$ badań $\mathrm{w}$ laboratorium problemów rozwoju osobowości osób z OMZ z Instytutu Problemów Edukacji Integracyjnej Moskiewskiego 
Uniwersytetu im. Łomonosowa w latach 2010-2012 ${ }^{19}$, warunkowo zdrowi studenci i studenci z OMZ przejawiają różną strukturę samoregulacji, pojęcie o jakości życia, sposób relacji ze światem. Samoregulacja to zdolność korygowania własnych działań $\mathrm{w}$ kierunku zmniejszenia różnic pomiędzy faktycznym stanem rzeczy i stanem pożądanym, na podstawie przewidywania oczekiwanych rezultatów. Samoregulacja wyrażona jest nie u wszystkich $\mathrm{w}$ równym stopniu, co znajduje odzwierciedlenie w pojęciu osobowościowego potencjału ${ }^{20}$. Przez osobowościowy potencjał rozumie się kompleks psychologicznych właściwości i struktur, które odpowiadają za powodzenie samoregulacji człowieka w szerokim znaczeniu tego słowa. Osobowościowy potencjał w szczególności niweluje wpływ traumatycznych sytuacji na zdrowie i psychiczne samopoczucie.

Niepełnosprawność może występować i realnie występuje (nie u wszystkich i nie zawsze, ale u wielu ludzi, którzy stoją w obliczu tego wyzwania) jako konstruktywny środek budowy jakościowo unikatowego systemu samoregulacji, który nie występuje u względnie zdrowych studentów: wada fizjologiczna występuje $\mathrm{w}$ niej nie jako negatywne wydarzenie, lecz jako oparcie, centrum, wokół którego budowane jest życie, główne źródło w bu-

${ }^{19}$ L. A. Aleksandrova, A. A. Lebedeva, D. A. Leontiev, Psychology of stress and coping behavior in present day Russian society. Proceedings of the Second International scientific-practical conference, Kostroma 2010, vol. 2, pp. 176-177; L. A. Aleksandrova, A. A. Lebedeva, D. A. Leontiev, E. I. Rasskazova. In: Leontiev D. A. (ed.) Personality potential: structure and assessment, Sens, Moskwa 2011, pp. 579-610; D. A. Leontev, L. A. Aleksandrova, A. A. Lebedeva, The specifics of resources and mechanisms of psychological resilience in physically challenged students in the context of inclusive education, Psychological science and education, 2011, no. 3, pp. 80-94; A. A. Lebedeva, Subjective well-being of physically challenged subjects. Ph. D. (Psychology) Thesis, Moscow 2012, 32 p.; L. A. Aleksandrova, D. A. Leontiev, A. A. Lebedeva, Essentials of the psychological educational work with physically challenged students in the inclusive educational context. In: Alehina S.V. (ed.), Psychopedagogical foundations of the inclusive education, Moscow, MGPPU; „Buki Vedi”, 2013, pp. 219-254; D. A. Leontiev, A. A. Lebedeva, L. A. Aleksandrova, Psychological mechanisms and resources of personality development in physically challenged students. In: S. V. Alehina (ed.), Psychopedagogical foundations of the inclusive education, Moscow 2013, pp. 116-149.

${ }^{20} \mathrm{D}$. A. Leontiev, The personal in the person: personality potential as the basis of self-determination. In B. S. Bratus (eds.), Proceedings of the department of general psychology of Moscow State University, vol. 1, Smysl, Moscow 2002, pp. 56-65; D. A. Leontiev, Personality potential as the potential of self-regulation. In B. S. Bratus (eds.), Proceedings of the department of general psychology of Moscow State University, vol. 2, Smysl, Moscow 2006, pp. 85-105; D. A. Leontiev, Personality potential as the potential of self-regulation. In D. A. Leontiev (ed.), Personality potential: structure and assessment, Smysl, Moscow 2011, pp. 107-130. 
dowaniu systemu samoregulacji. Jest pewnym paradoksem, że im silniejsza wada i ograniczenia, tym bardziej pozytywne są zmiany, bardziej wyraźny wzrost. Innymi słowy, ograniczone możliwości zdrowia i wada przekształcają się w zasób osobowości. Jeżeli stosunek między dostępnymi zasobami niezbędnymi do sprostania zadaniom a liczbą zadań nie jest zbyt korzystny, to możliwe są dwie strategie wyboru drogi do tego, aby „nasze pragnienia pokrywały się z naszymi możliwościami”: albo obniżyć poprzeczkę, ograniczyć liczbę i skalę zadań i uprościć sobie życie, albo jakimś sposobem zwiększać dostępne i szukać nowych zasobów.

Cielesne zasoby pacjentów z OMZ to deficyty wynikające z definicji. Społeczne zasoby mogą być różne; jednak ich niewystarczalność można kompensować dodatkową społeczną pomocą. $\mathrm{W}$ przeciwieństwie do tego nie możemy dać człowiekowi osobowościowych zasobów w razie ich niewystarczalności. Możemy jedynie próbować je aktywizować, ułatwić do nich dostęp, zapewnić moralne, psychologiczne i metodologiczne wsparcie dla strategii rozwijających i dla odpowiedzi na życiowe wyzwania, jeśli jednostka gotowa je podjacć. Ogólna zasada, która powinna być niezbędnie stosowana $\mathrm{w}$ kontaktach $\mathrm{z}$ osobami z ograniczonymi możliwościami zdrowia (OMZ) (i nie tylko z nimi), to zasada wspólnego działania, zakładająca, że nie można człowiekowi dostarczyć deficytowych zasobów osobowych, ale można pomóc $\mathrm{w}$ ich rozwijaniu. $\mathrm{W}$ tym celu niezbędne jest: po pierwsze, stworzenie albo uaktualnienie dla nich możliwość wyboru, i po drugie wspieranie tego wyboru, który prowadzi do pozytywnych dla nich następstw.

Co więcej, pewne osobowościowe środki rozwoju studentów z OMZ znajdują się na wyższym poziomie niż ich „stosunkowo zdrowych” rówieśników, co związane jest $\mathrm{z}$ ich większym zapotrzebowaniem, koniecznością i co za tym idzie - wyćwiczeniem. W pierwszej kolejności chodzi o środki, związane ze skomplikowaną czynnością rozwiązywania zadań, których nie udaje się rozwiązać prostymi, szablonowymi sposobami. Ta uniwersalna teza, że rozwiązywanie życiowych zadań i rozwój osobowości są czynnościami pracochłonnymi, dla młodych ludzi z OMZ jest wypełniona wyraźną treścią - przecież dla nich rozwiązanie nawet zwykłych codziennych i szablonowych sytuacji wymaga mobilizacji wielu środków, uwagi, świadomości, podwyższonego zaangażowania. $\mathrm{W}$ tym samym czasie stosunkowo zdrowi studenci z podobnymi psychologicznymi problemami często rozwiązują zadania dzięki stosowaniu stereotypowych mechanizmów obronnych i radzenia sobie. 
Kompensacyjna rola osobowościowych zasobów w odniesieniu do fizycznych deficytów uwarunkowana jest przez to, że fizyczne funkcje przy ich prawidłowym zachowaniu pracują jako „organy funkcjonalne” człowieka, zapewniając sprawność i automatyczne działanie niektórych czynności. $\mathrm{W}$ przypadku ich nieprawidłowości następuje deautomatyzacja, co wymaga zaangażowania osobowości i świadomości. Z jednej strony osobom niepełnosprawnym jest znacznie trudniej, $z$ drugiej strony daje im to określone psychologiczne zalety, albowiem procesy odbywające się pod kontrolą świadomości, po pierwsze, nierzadko doprowadzają do przeżycia przepływu, po drugie przyczyniają się do rozwoju.

Fizyczne i społeczne zasoby występują jako funkcjonalne elementy rozszerzania możliwości indywiduum. „Osobowość jako otwarty system doświadcza niezaspokojonej, wskutek swojej uniwersalnej natury, potrzebuje amplifikacji (rozbudowania) (A. W. Zaporożec), rozszerzania i wzbogacenia „krajobrazu” swoich granic, kształtowania „elementów”, wzmacniających życiowe kompetencje osobowości” ${ }^{21}$. W roli takich „funkcjonalnych elementów", poszerzających indywidualne możliwości, występują relacje społeczne, grupy i instytucje: „osobowość jako otwarty system może uczynić swoim funkcjonalnym „elementem” zarówno wspólnotę społeczną, jak i całe społeczeństwo"22.

Deficyty zasobów społecznych mogą być generowane nie tylko przez indywidualne okoliczności, ale także poprzez naruszenia struktury społeczeństwa i jego społecznego funkcjonowania. Właśnie do tego dochodzi w dzisiejszym społeczeństwie rosyjskim, gdzie pewne instytucje społeczne i ich funkcje nie działają prawidłowo. Można powiedzieć, że przytłaczająca większość Rosjan znajduje się w sytuacji „społecznej niepełnosprawności” albo „ograniczonych możliwości społecznych", kompensując różne deficyty wzrostem mobilizacji, deautomatyzacją i nadmiernym inwestowaniem zasobów osobowościowych.

Tak więc trzy grupy czynników, które przyczyniają się do rozwoju osobowości, są komplementarne i częściowo kompensują siebie nawzajem. Oto niektóre konkretne hipotezy na temat oddziaływania tych czynników, które można wywnioskować z powyższych rozważań, a które obecnie znajdują potwierdzenie w wynikach badań naszego laboratorium:

${ }^{21}$ L. I. Ancyferova, Personality development and problems of gerontopsychology, Moscow 2006, 511 p., c. 243.

${ }^{22}$ Tamże. 
1. U osób z OMZ samopoczucie psychiczne w większym stopniu zależy od dostępności wsparcia społecznego i satysfakcji z niego niż u względnie zdrowych.

2. U osób z OMZ samopoczucie psychiczne w większym stopniu zależy od nasilenia osobowościowych zasobów samoregulacji niż u osób względnie zdrowych.

3. U osób z OMZ potrzeba pomocy społecznej jest bardziej widoczna niż u względnie zdrowych. Przy czym nie zawsze jest ona adekwatnie uświadomiona i nie każda forma pomocy społecznej może tę potrzebę zaspokoić.

4. U osób z OMZ może dominować albo strategia preferowania korzystania z pomocy społecznej, albo strategia oparcia głównie na osobowościowych zasobach samoregulacji jako podstawowych środkach kompensacji ograniczonych możliwości zdrowia. To zależy przede wszystkim od dostępności środków pomocy społecznej.

5. U osób z OMZ bardziej niż u względnie zdrowych osób widoczne są skutki wzrostu pourazowego, które odgrywają rolę środka radzenia sobie $\mathrm{z}$ trudną sytuacją. Przez pourazowy wzrost rozumiemy paradoksalne skutki pozytywnych zmian niektórych aspektów osobowości pod wpływem sytuacji traumatycznych. Takie efekty dają się zaobserwować nie zamiast negatywnych zmian, typowych dla zespołu stresu pourazowego (PTSD), ale jednocześnie $\mathrm{z}$ nimi są $\mathrm{w}$ stanie wyeliminować dużą część negatywnych następstw urazu ${ }^{23}$. Pourazowy wzrost jest mniej zauważalny w przypadku osób w sytuacji psychotraumatycznej. Być może jest to konsekwencją przyjęcia wyzwania, polegającego na gotowości do realizacji pracy nad samym sobą.

\section{Podsumowanie}

$\mathrm{W}$ artykule tym poruszona została kwestia istoty rozwoju osobowości w utrudnionych warunkach, które nie mogą być opisane w sposób właściwy i dokładny przy użyciu normalnych modeli rozwoju i modeli rozwoju $\mathrm{z}$ odchyleniami. Wydaje się jednak, że na przykładzie utrudnionych warunków ogólne psychologiczne mechanizmy rozwoju osobowości są najbardziej widoczne. Kluczowe $\mathrm{w}$ tych mechanizmach jest współdziałanie w trakcie

${ }^{23}$ L. Calhoun, R. Tedeshi (eds.), Handbook of Posttraumatic Growth. Research and Practice, Lawrence Erlbaum, Mahwah 2006, XII, 387 p. 
osobowościowego rozwoju biologicznego, społecznego i właściwie osobowościowego wymiarów, współoddziaływanie zadań biologicznego dojrzewania, socjalizacji, personalizacji i kilku grup środków, przyczyniających się do rozwiązania tych kwestii. Przy czym w utrudnionych warunkach deficytu pewnych zasobów, inne mogą odgrywać kompensującą rolę. Szczególna rola, jak staraliśmy się pokazać, należy do osobowościowych zasobów, które stanowią „ostatnią linię obrony” przeciwko niesprzyjającym warunkom rozwoju. Operacjonalizacja tego modelu została pomyślnie przeprowadzona na studentach z OMZ. Zarazem można zauważyć, model ten ma szerszy zakres zastosowania i może znaleźć zastosowanie w ogólnej i klinicznej psychologii osobowości, psychologii zachowań dewiacyjnych, psychologii sportu, a nawet w psychologii pracy i organizacji.

Przekład i opracowanie Aleksandra Kondrat

\section{Bibliografia}

Adler A., Studie über Minderwertigkeit von Organen, Berlin: Urban \& Schwarzenberg 1907, 127 p. Zob. A. Adler, Sens życia, tłum. Maria Kreczowska, Warszawa 1986. Aleksandrova L. A., Lebedeva A. A., Leontiev D. A., [Coping strategies: an attempt of the systematic charecterization]. Psychology of stress and coping behavior in present day Russian society. Proceedings of the Second International scientific-practical conferencevol. 2, Kostroma 2010.

Aleksandrova L. A., Leontiev D. A., Lebedeva A. A., Essentials of the psychological educational work with physically challenged students in the inclusive educational context. In Alehina S.V. (ed.), Psychopedagogical foundations of the inclusive education, Moscow: MGPPU, 2013.

Aleksandrova L. A., Lebedeva A. A., Leontiev D. A., Rasskazova E. I., [Personality resources of overcoming complicated developmental conditions]. In Leontiev D.A. (ed.) Personality potential: structure and assessment, Moskwa, Sens, 2011.

Ancyferova L. I., Personality development and problems of gerontopsychology, Moscow: Instytut Psychologii RAN, 2006, 511 p.

Белопухов А.К., Я - спинальник. (Чуть медленнее чем Andante), Москва 1993.

Calhoun L., Tedeshi R. (Eds), Handbook of Posttraumatic Growth. Research and Practice, Mahwah: Lawrence Erlbaum, 2006, XII, 387 p.

Csíkszentmihályi M., Поток: психология оптимального переживания [Przeplyw: Psychologia optymalnego doświadczenia], Москва 2011.

Dąbrowski K., Positive Disintegration, Boston: Little, Brown, and Co, 1964. 
Lebedeva A. A., Subjective well-being of physically challenged subjects. Ph.D. (Psychology) Thesis, Moscow, 2012.

Леонтьев А., Activity, consciousness, and personality, Moscow 1977.

Леонтьев А., Личностное изменение человеческого развития [Osobisty wymiar ludzkiego rozwoju], „Вопросы психологии., 2013, $\mathrm{nr} 3$.

Леонтьев Д. А., Психологические основы развития ребенка и обучения, [Psychologiczne podstawy rozwoju i uczenia się dzieci], Москва, Смысл [Sens], 2009.

Леонтьев Д. А., Психология смыста, [Psychologia sensu], Москва 1999.

Леонтьев Д. А., Развитие личности в норме и в затрудненных условиях, „Cultural-Historical Psychology", 2014. Vol. 10, no. 3.

Леонтьев Д. А., Рассказова Е. И., Тест жизнестойкости [Test odporności życiowej], Москва, 2006.

Leontiev D. A., Personality potential as the potential of self-regulation]. In B. S. Bratus (eds.), Proceedings of the department of general psychology of Moscow State University, vol. 2, Moscow, Smysl, 2006.

Leontiev D. A., Personality potential as the potential of self-regulation]. In D. A. Leontiev (ed.), Personality potential: structure and assessment, Moscow, Smysl, 2011.

Leontiev D. A., Lebedeva A. A., Aleksandrova L. A., Psychological mechanisms and resources of personality development in physically challenged students]. In S. V. Alehina (ed.), Psychopedagogical foundations of the inclusive education, Moscow, MGPPU, 2013.

Leontiev D. A., The personal in the person: personality potential as the basis of selfdetermination. In B. S. Bratus (eds.), Proceedings of the department of general psychology of Moscow State University, vol. 1, Moscow, Smysl, 2002.

Leontev D. A., Aleksandrova L. A., Lebedeva A. A., The specifics of resources and mechanisms of psychological resilience in physically challenged students in the context of inclusive education, Psychological science and education, 2011, no. 3 .

Лурия А.Р., Высшие корковые функции человека и их нарушения при локальных поражениях мозга [Wyższe funkcje korowe człowieka i ich zaburzenia przy miejscowych uszkodzeniach mózgu], Москва 1969.

Semago M. M., Developmental psychology in the postnonclassical scientific world view, Moscow, Publ. APK and PPRO, 2010.

Slobodskaya H. R., Akhmetova O. A., Rippinen T. O., Does personality matter more in difficult circumstances?, "Journal of Research in Personality", 2014, Vol. 48.

Василюк Ф. Е., Психология переживания: анализ преодоления критических ситуаций, Москва 1984. 


\section{Abstract \\ Personality Development in Normal and Complicated Conditions}

The paper is devoted to the features of personality development in physically challenged individuals, which is conceptualized as the development in complicated conditions, distinct from both normal and abnormal development. Goals, direction and criteria of the development in complicated conditions do not differ from the normal development case, but the deficit of a certain category of developmental resources requires extra mobilization of other resources and increases the efforts the individual needs to apply to attain the goals of development. The theoretical model proposed in the paper describes personality development through the mechanisms of interaction of bodily, social and personal resources, some of them compensating for the deficit of others. The developmental situation of the physically challenged individual is characterized by this very challenge; accepting it implies the construction of a specific system of activity regulation based on the compensation for the deficient bodily resources by virtue of personal resources. The character of this compensation largely depends on the availability of macrosocial and microsocial resources of social support.

Key words: personality, physical challenge, development, bodiness, resources, challenge, social support 